\title{
Experimental of Mechanical Properties in Glass Fiber by using Epoxy and Polyester Resin
}

\section{Kumaravel, E. Gopinath}

Abstract: Alkali Resistant Glass Fibers are designed specifically for use in concrete. It is made from a specially developed glass composition of zirconium dioxide which is appropriately used in concrete. It is to evaluate and compare the physical and mechanical properties of laminates prepared of different composition of Glass fiber. In this experiment, two specimens with different composition was taken and prepared by using hand layup method. Tensile test, Impact test and Brinell hardness test were carried out and their performances were evaluated. In this experiment, composite was subjected to water absorption test. From the result, property of two specimen was compared and analyzed.

Keywords : composite, epoxy, glass fiber, , polyester resin

\section{INTRODUCTION}

Composites have gained such lot recognition attributable to their process benefits and smart technical properties like strength, density, impact, stiffness, modulus, creep rate and damping. Composite is one which is made with more than two materials to obtain the required property. At present, composite play a vital role in industrial application. By selecting the proper material for composite, quality of the product can be improved. Most composite materials have a bulk section which continuously referred to as the matrix and one spread non-continuous section referred to as the reinforcement which is tougher and stronger. Glass fiber is a typical reinforcing material for thermosetting matrices having numerous structural applications.

\section{EXPERIMENTATION}

Resin is a viscous substance of plant or artificial origin that is usually convertible into polymers. In this project epoxy and polyester resin were used. By the addition of 150 milliliter of hardener to one litre of resin and mix it gently for 2 minutes, the epoxy resin was prepared. In a same way, by the addition of 10 milliliter of peroxide and 15 milliliter of accelerator with one litre of resin, the polyester was prepared. The details of the various composite materials are given in Table-I. The composite specimens as per the above combination were prepared by hand layout method with the dimensions of $250 \mathrm{~mm} \times 250 \mathrm{~mm} \times 10 \mathrm{~mm}$. The setup is kept undisturbed for 24 hours in the room temperature for the matrix to set properly. The prepared composites were cut for testing as per American Society for Testing and Materials.

Revised Manuscript Received on December 5, 2019.

* Correspondence Author

D. Kumaravel *, Department of Mechanical Engineering, Academy of Maritime Education and Training, Chennai, India. Email: kevinkumaravel@gmail.com

E.Gopinath, Department of Mechanical Engineering, Sri Shanmugha College of Engineering and Technology, Salem, India. Email: gopinath619@rediffmail.com

\begin{tabular}{|c|c|c|}
\hline \multicolumn{2}{|c|}{ Table- I: Composite Detail } \\
\hline 1 & $\begin{array}{c}\text { Material } \\
\text { Description }\end{array}$ & $\begin{array}{c}\text { Material } \\
\text { Details }\end{array}$ \\
\hline 2 & Specimen 1 & $\begin{array}{c}\text { Fiber+ } \\
\text { Epoxy resin }\end{array}$ \\
\hline & Specimen 2 & $\begin{array}{c}\text { Fiber }+ \\
\text { polyester }\end{array}$ \\
\hline
\end{tabular}

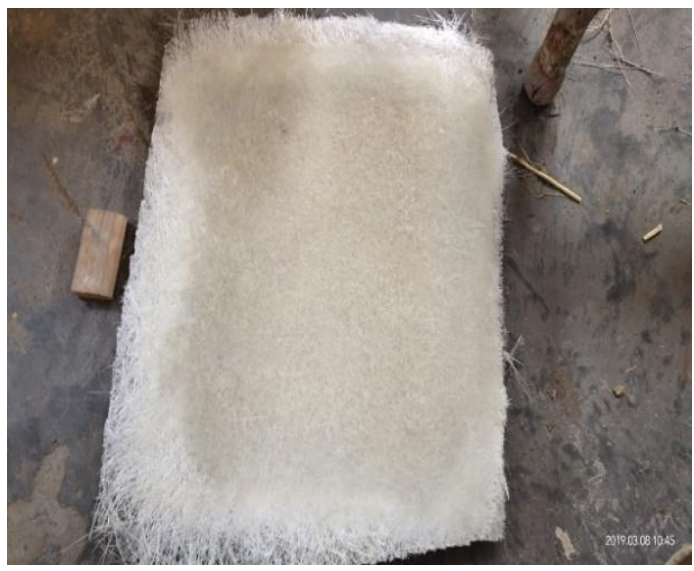

Fig. 1. Composite prepared by Hand layup Process.

\section{TESTING AND RESULT}

\section{A. Tensile Test}

The composite specimen was cut as per American Society for Testing and Materials standard. Specimen prepared by polyester withstand the load up to $55 \mathrm{KN}$, but epoxy mixed specimen break within $18 \mathrm{KN}$ load. Hence, it was noticed from the testing result that, the fabricated composite specimen polyester has shown the greater improvement when compared to epoxy. The details of the tensile test reading are shown in Table-II.
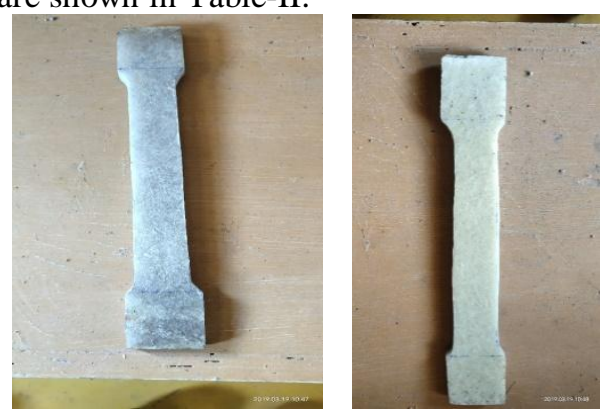

Before test 

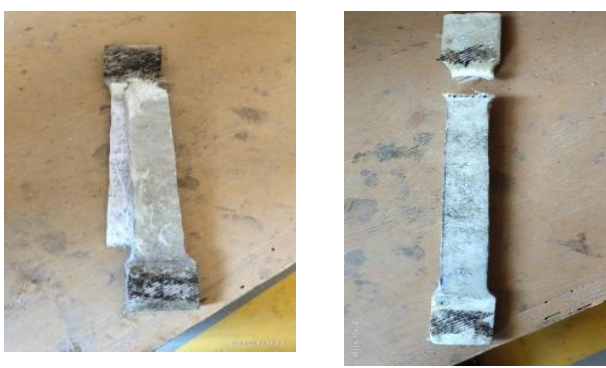

After test

Fig. 2. Tensile test specimen

Table- II: Tensile test result

\begin{tabular}{|c|c|c|c|}
\hline Specimen & $\begin{array}{c}\text { Yield } \\
\text { Load } \\
(\mathbf{K N})\end{array}$ & $\begin{array}{c}\text { Ultimate } \\
\text { Load } \\
(\mathbf{K N})\end{array}$ & $\begin{array}{c}\text { Breaking } \\
\text { Load } \\
(\mathbf{K N})\end{array}$ \\
\hline $\begin{array}{c}\text { Specimen 1 } \\
\text { (Polyester) }\end{array}$ & 65 & 70 & 55 \\
\hline $\begin{array}{c}\text { Specimen 2 } \\
\text { (Epoxy) }\end{array}$ & 21 & 26 & 18 \\
\hline
\end{tabular}

\section{B. Charpy Test}

Hardness property of fabricated composite specimen was evaluated with the aid of impact testing machine. The composite specimen was prepared as per American Society for Testing and it was noticed that, the hardness property of epoxy specimen had high impact strength of $7.125 \mathrm{~J} / \mathrm{m}^{2}$. The values of the impact test are shown in Table-III.
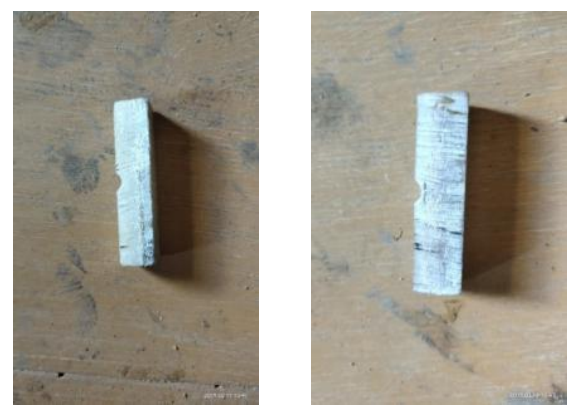

Before Test
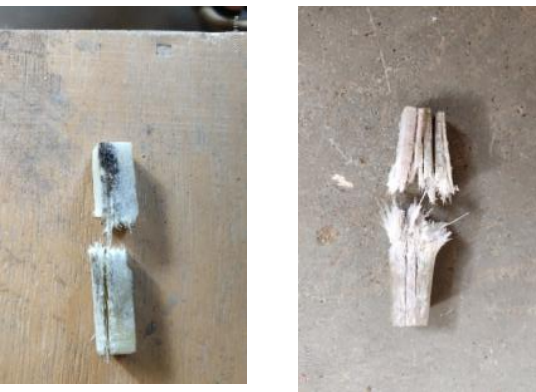

After test

Fig. 3. Charpy test specimen

Table- III: Charpy test result

\begin{tabular}{|l|c|c|}
\hline \multirow{3}{*}{ Specimen } & Impact & Impact \\
& Energy Observed & Strength \\
& $(\mathbf{J})$ & $\left(\mathbf{J} / \mathbf{m}^{2}\right)$ \\
\hline
\end{tabular}

\begin{tabular}{|l|c|c|}
\hline $\begin{array}{l}\text { Specimen 1 } \\
\text { (Epoxy) }\end{array}$ & 570 & 7.125 \\
\hline $\begin{array}{l}\text { Specimen 2 } \\
\text { (Polyester) }\end{array}$ & 550 & 6.875 \\
\hline
\end{tabular}

\section{Brinell Hardness Test}

Brinell technique applies a preset check load to an in organic compound ball of fastened diameter that is command for a preset period of time. The ensuring impression is measured with a specially designed Brinell magnifier. The BHN value of two specimen are shown in Table-IV.

Table- IV: Hardness test result

\begin{tabular}{|c|c|c|c|c|}
\hline Specimen & $\begin{array}{c}\text { Ball } \\
\text { Diameter } \\
(\mathbf{m m})\end{array}$ & $\begin{array}{c}\text { Load } \\
\text { Applied } \\
(\mathbf{K g})\end{array}$ & $\begin{array}{c}\text { Diameter } \\
\text { Indentation } \\
(\mathbf{m m})\end{array}$ & BHN \\
\hline $\begin{array}{c}\text { Specimen 1 } \\
\text { (Epoxy) }\end{array}$ & 10 & 1000 & 7 & 22.27 \\
\hline $\begin{array}{c}\text { Specimen 2 } \\
\text { (Polyester) }\end{array}$ & 10 & 1000 & 8 & 15.91 \\
\hline
\end{tabular}

\section{Water absorption test}

Water absorption test was conducted on composite material to find the capability of material to withstand water during industrial application. In this experiment, material was made to dry for one hour at $40^{\circ} \mathrm{C}$ and cool up to room temperature. It is done by immersing the material in water for $24 \mathrm{Hrs}$ and compares the weight of composite before and after immersion. From the result, absorption property can be obtained.
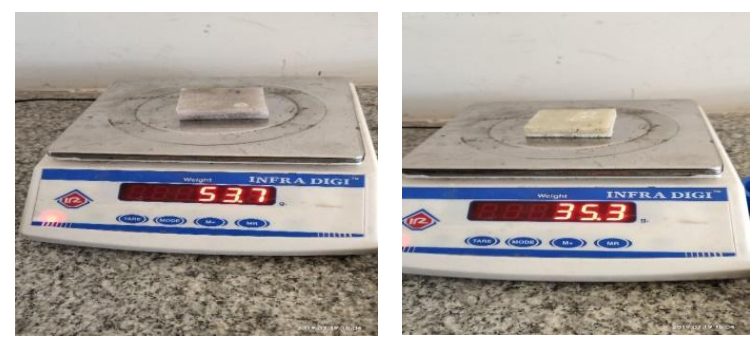

Before test
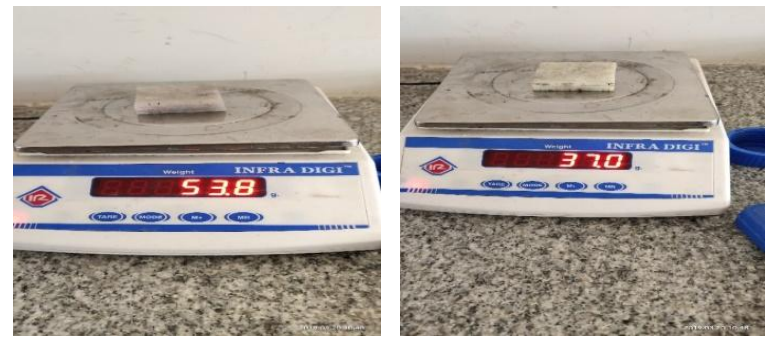

After test

Fig. 4. Water absorption test

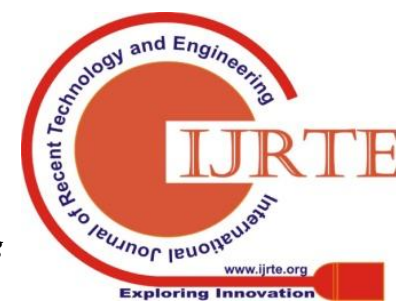


Table- V: Water absorption test result

\begin{tabular}{|c|c|c|}
\hline $\begin{array}{c}\text { Specimen } \\
\text { description }\end{array}$ & $\begin{array}{c}\text { Weight before test } \\
\text { (gm.) }\end{array}$ & $\begin{array}{c}\text { Weight after 24 } \\
\text { hours } \\
\text { (gm.) }\end{array}$ \\
\hline $\begin{array}{c}\text { Specimen 1 } \\
\text { (Epoxy) }\end{array}$ & 35.3 & 37 \\
\hline $\begin{array}{c}\text { Specimen 2 } \\
\text { (polyester) }\end{array}$ & 53.7 & 53.8 \\
\hline
\end{tabular}

\section{CONCLUSION}

This experiment shows that successful fabrication of glass fiber with Epoxy and Polyester resin composites is possible and very cost effective by simple hand lay-up technique. Testing was done on two specimens with different composition and result was analyzed. It is concluded from the above testing that the Glass fiber with Epoxy resin having good hardness and impact strength as compare with polyester. But the specimen made with polyester having good tensile property.

\section{REFERENCES}

1. Ajith Gopinath, "Experimental Investigations on Mechanical Properties Of Jute Fiber Reinforced Composites with Polyester and Epoxy Resin Matrices”, Procedia Engineering, 2014, vol. 97, pp. 2052-2063.

2. Hasim Pihtili, "An experimental investigation of wear of glass fibre-epoxy resin and glass fibre-polyester resin composite materials", European Polymer Journal, 2009, Vol. 45, pp. 149-154.

3. D.kumaravel, "Investigation on Tensile Strength of Water Hyacinth-Coconut Shell Powder Reinforced Hybrid Eco Composite", Applied mechanics and materials, 2015, Vol. 766, page 57 to 62 .

4. Caroline G. deOliveira, "Comparison between tensile behavior of epoxy and polyester matrix composites reinforced with eucalyptus fibers", Journal of Materials Research and Technology, 2017, vol. 6, pp. 406-410.

5. Yayun Liu, "Carbon fiber reinforced shape memory epoxy composites with superior mechanical performances", Composites Science and Technology, 2019, vol. 177, pp. 49-56.

6. N.V.Rachchh, Mechanical Characterisation of Rattan Fibre Polyester Composite, Procedia Materials Science, 2014, vol. 6, pp. 1396-1404.

7. Tolera A.Negawo, "Mechanical, morphological, structural and dynamic mechanical properties of alkali treated Ensete stem fibers reinforced unsaturated polyester composites", Composite Structures, 2019, vol. 207, pp. 589-597.

8. R.Giridharan, "Preparation and property evaluation of Glass/Ramie fibers reinforced epoxy hybrid composites", Composites Part B: Engineering, 2019, vol. 167, pp. 342-345.

9. Piyush Prajapati, "Evaluation of Mechanical Properties of Coir and Glass Fiber Hybrid Composites", Materials Today: Proceedings, 2018, vol. 5, pp- 19056-19062.

10. SongWang, "Effects of hybrid water Immersion, environmental exposures, and axial load on the mechanical properties of concrete filled epoxy-based glass fiber reinforced polymer tubes", Construction and Building Materials, 2019, vol. 194, pp. 311-321.

\section{AUTHORS PROFILE}

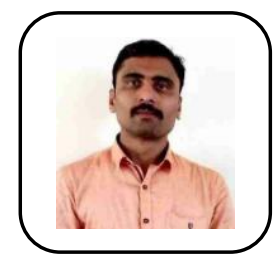

D. Kumaravel has completed his bachelor degree in Mechanical Engineering and master degree in Manufacturing Engineering. He has presented many papers in international conference and published many papers in reputed journals.

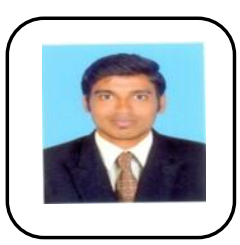

E. Gopinath has completed his bachelor degree in Mechanical Engineering and master degree in Manufacturing Engineering. He has presented many papers in international conference and published many papers in reputed journals. 